\begin{tabular}{|c|c||}
\hline Sciendo & $\begin{array}{c}\text { RURAL SUSTAINABILITY RESEARCH 41(336), 2019 } \\
\text { ISSN - 2256-0939 } \\
\text { C Latvia University of Life Sciences and Technologies, } \\
\text { all rights reserved } \\
\text { http://www.llu.lv/en/ }\end{array}$ \\
\hline \hline
\end{tabular}

\title{
Effect of Agripreneurship on Employment and Income Generation in Cattle Fattening Business in Nigeria
}

\author{
*Abiodun Elijah Obayelu ${ }^{1}$, Ajibola Olaniyi ${ }^{2}$, Agatha Ogbe ${ }^{3}$ \\ Federal University of Agriculture ${ }^{1}$, Abeokuta, Nigeria \\ Youth Agripreneurs Unit² ${ }^{2}$ Ibadan, Nigeria
}

\begin{abstract}
Unemployment is a major issue in Nigeria because the youth finds it difficult or impossible to secure jobs that meet their expectations. There appears to be a mismatch between graduate skills and those sought by employers. The study investigated the effect of International Institute of Tropical Agriculture (IITA) youth Agripreneurs (IYA) programme on employment and income generation on cattle fattening enterprise under the N2Africa Borno youth project. A two-stage sampling procedure was used to select IYA participants and non-participants. Results revealed that the majority of respondents were males in both categories. It also indicated that youths who are in their productive age are more into cattle fattening enterprise in both categories. The study also found that, unemployment and skill acquisition are the main driving reasons for participating in IYA. It also indicated that both categories of respondents' required external capital support for start-up of their enterprise, and that IYA programme participants on the average earn more income per month than nonparticipants. IYA programme participants generated more employment opportunities which implied that the programme had not only empowered participants but also made the participants' become employers. The study recommended that there is a need to support youths with funds, access to trainings on capacity development and skill acquisition to make them self-employed and job creators.
\end{abstract}

Keywords: Agripreneurship, Youth empowerment, Job creation, Rural development, Capacity building.

\section{Introduction}

Unemployment creates a wide range of social ills and young people are particularly susceptible to its damaging effects: lack of skills, low self-esteem, marginalization, impoverishment and wasting of enormous human resources. The problems associated with unemployment can be solved by empowering and training the youths through agricultural development programmes to avail them the opportunities of being self-employed or being employers in agriculture and generate income on their own (Agu, 2013). To ensure that the youth are productively engaged in embracing agriculture as an opportunity to create jobs and earn decent living, several organizations have initiated programmes that could empower youth in Agriculture. One of such initiatives is the IITA Youth Agripreneurs model created by the International Institute of tropical Agriculture, IITA.

The International Institute of Tropical Agriculture (IITA) is one of the world's leading research partners in finding solutions to hunger, malnutrition, and poverty. Its research-for-development (R4D) approach addresses the development needs of tropical countries. IITA works with partners to enhance crop quality and productivity, reduce producer and consumer risks, and generate wealth from agriculture. The Institute is a member of the CGIAR, a global agriculture research partnership for a food secure future. Identifying that agriculture is an essential driver of youth empowerment and a sector that offers unique opportunities to secure jobs and skills for young people to grow agribusinesses in sub-Saharan Africa, IITA, created the IITA Youth Agripreneurs (IYA) in August 2012.

The programme is aimed at promoting independent in small-scale business models involving crop production such as cassava, banana/plantain, maize, soybean and vegetables. The choice of commodities considered in the programme was swayed by the main staple foods of the people living in rural areas, fast

\footnotetext{
* Corresponding Author's email:

obayelu@yahoo.com
}

DOI:10.2478/plua-2019-0003 
growing cities in Nigeria and the rest of Sub-Saharan Africa. The focus of IYA's was initially on production and distribution of quality seeds which has since incorporated value addition, business development and service delivery in consultancy and capacity building. The group has since diversified into animal production through catfish rearing and pigs' production aimed at producing low fat pork. Other commodities were however adopted based on market demand and analysis. IITA fully subsidised IYA's activities with grants from international organizations such as the Forum for Agricultural Research in Africa (FARA), the International Fund for Agricultural Development (IFAD), the African Development Bank (AfDB), the United States Agency for International Development (USAID), the Bill and Melinda Gates Foundation (BMGF), and the Federal Government of Nigeria (FGN) through the Federal Ministry of Agriculture and Rural Development (FMARD) during its first year of operation.

Youth involvement in agriculture has been a problem for many decades across Africa. Attempts have been made by many countries' governments in Africa (including the government of the Federal Republic of Nigeria) to stimulate the youth interest and participation in agriculture, and a lot needs to be done particularly in making agriculture attractive to the youth. Agriculture is the mainstay of most economy in West Africa and livestock production contributed close to $49 \%$ of the Nigerian gross domestic product (Amadou, et al., 2012). Nigerian youths have shown negative attitude towards livestock rearing and cattle fattening among other segments of agriculture as it is seen as labour intensive, long time investment, providing slow and low income opportunities, thus being unattractive (Adeiga, 1997; Erebor, 2003). Another factor that has affected the non-participation of youth in livestock production is lack of incentive. Cattle fattening is an integral component of agriculture and it helps in meeting high-protein food demand and plays an important role in enhancing food security, provision of employment and income to the household as well as investment opportunities (Sarma, Raha, \& Jorgensen, 2014). In Nigeria, livestock production has not been able to meet domestic consumption demand. Animal fattening is a highly profitable enterprise and improvement in local beef fattening enterprise; however, it is also a financial constraint (Umar, Alamu, \& Adeniji, 2008). This study is an attempt to investigate the effect of IITA Youth Agripreneurs (IYA) on employment and income generation on cattle fattening in the study area.

The objectives of the study are to: (i) identify the socio-economic characteristics of youth involved in cattle fattening; (ii) identify the reasons for participating in IYA programme; (iii) assess the amount of income and employment generated through IYA in fattening business.

\section{Materials and Methods}

The study was conducted in Biu Local Government (LGA) in Southern Borno State of Nigeria. It has a population projection of 246,900 in 2016 and an area of $3,315 \mathrm{~km}^{2}$. The LGA is located in the Northern Guinea Savannah agro-ecological zone and it exhibits a mixed agricultural based economy: herding cattle, goat, sheep among others and cultivation of crops: sorghum, millet, maize, cowpea and cotton.

The study used a two-stage sampling procedure to select the sample size. The first involved the purposeful selection of 81 youths from the three hundred youths trained under the IYA programme who are involved in cattle fattening enterprise. The second stage involved the random selection of 60 youths who are none participants of IYA programme. A total of 141 youths were used for the study. Primary data were used for the study and collected using questionnaire. The analytical technique used for this study was descriptive statistics. Descriptive statistic such as frequency table was used for objectives 1,2 and 3 .

\section{Results and Discussion}

\section{Distribution of Respondents by Socio-economic Characteristics}

The result of the socio-economic characteristics of respondents is presented in Table 1. The result shows that the majority of the respondents are males in both categories (participant (74) and non-participant (55). This could be likened to the fact that cattle fattening is labour intensive and requires more physical strength (attributed mostly to a male) to handle the animals. The result of this study follows that of Sarma, Raha, \& Jorgensen (2014); Mohammed, Mohammed, \& Dahiru, (2015). With respect to the age of respondents, the result revealed that youths within the productive age bracket of $21-30$ are more into cattle fattening enterprise in both categories: participant (34) and non-participant (36). This is due to the fact that cattle fattening is laborious and require active individual. This is in consonance with Mohammed, Mohammed, \& Dahiru, (2015). The distribution of the participants based on their level of education shows that all respondents in both categories: participants (80) and non-participants (56) have one form of western education or the other. This implies that by being educated will make the respondent open to adoption of improved technology 
(Okoye, Okorji \& Asumugha, 2007) relating to cattle fattening which will improve their income level. This finding is in line with Sarma and Ahmed, (2011); Sarma, Raha, \& Jorgensen (2014); Mohammed, Mohammed, \& Dahiru, (2015). In terms of household size, majority of the respondents in both categories: with participants (79) and non-participants (50) having a household size range of $1-10$ persons. This implies that a household member could provide a source of labour (family labour) for their cattle fattening enterprise. In terms of the number of years in cattle fattening business, the majority of the respondents (42) in the non-participants' category have greater years of experience than the IYA participants. This could be due to the fact that some of the non-participants have been in the business all their lives.

Socio-Economic Characteristics of the Respondents

\begin{tabular}{|c|c|c|}
\hline Socio-economic Characteristics & Participant $(\mathrm{n}=81)$ & Non - participant $(n=60)$ \\
\hline & Frequency & Frequency \\
\hline \multicolumn{3}{|l|}{ Age (years) } \\
\hline$\leq 20$ & 15 & 12 \\
\hline $21-30$ & 34 & 36 \\
\hline $31-40$ & 32 & 12 \\
\hline \multicolumn{3}{|l|}{ Sex } \\
\hline Male & 74 & 55 \\
\hline Female & 7 & 5 \\
\hline \multicolumn{3}{|l|}{ Marital Status } \\
\hline Single & 33 & 8 \\
\hline Married & 48 & 42 \\
\hline \multicolumn{3}{|l|}{ Education (years of schooling) } \\
\hline Vocational/Technical & 1 & 4 \\
\hline Primary education & 0 & 0 \\
\hline Secondary education & 0 & 0 \\
\hline OND (Ordinary National Diploma) & 18 & 22 \\
\hline HND (Higher National Diploma) & 26 & 28 \\
\hline B.Sc & 36 & 6 \\
\hline \multicolumn{3}{|l|}{ Household size (number of persons) } \\
\hline $1-5$ & 41 & 20 \\
\hline $6-10$ & 38 & 30 \\
\hline $11-15$ & 2 & 10 \\
\hline \multicolumn{3}{|l|}{ Employment Status } \\
\hline \multicolumn{3}{|l|}{ Cattle fattening as primary occupation } \\
\hline Yes & 73 & 25 \\
\hline No & 8 & 35 \\
\hline \multicolumn{3}{|l|}{ Secondary occupation } \\
\hline Input supply & 34 & 9 \\
\hline Grain market & 20 & 6 \\
\hline Trading & 10 & 5 \\
\hline Poultry & 8 & 3 \\
\hline Livestock & 1 & 2 \\
\hline
\end{tabular}




\begin{tabular}{|l|c|c|}
\hline \multicolumn{1}{|c|}{ Socio-economic Characteristics } & Participant $(\mathrm{n}=81)$ & Non - participant $(\mathrm{n}=60)$ \\
\hline \multicolumn{3}{|c|}{ Frequency } \\
\hline Membership of cooperative society & 4 & 2 \\
\hline Yes & 77 & 58 \\
\hline No & 23 & 5 \\
\hline Experience in cattle fattening (years) & 40 & 5 \\
\hline 1 & 18 & 8 \\
\hline 2 & 0 & 42 \\
\hline 3 & & Frequency \\
\hline$\geq 4$ & 25 & Not available \\
\hline Year of participation in the IYA programme & 41 & Not available \\
\hline 2014 & 10 & Not available \\
\hline 2015 & 5 & Not available \\
\hline 2016 & & \\
\hline 2017 &
\end{tabular}

Source: Field survey, 2018

The results in Table 1 implied that most youths in cattle fattening business in Nigeria are males, educated with at least Ordinary National Diploma certificate, married, not members of cooperative society, have some other secondary occupations with less than 3 years of experience in cattle fattening business.

Reasons for Participating in IYA Programme by the Respondents

The result of the reasons why respondents participated in the IYA programme is presented in Table 2. The result revealed that 39 and 34 of the respondents indicated that unemployment and skill acquisition respectively are the main driving reasons for participating in IYA.

Table 2

\section{Reasons for Participating in IYA Programme}

\begin{tabular}{|l|c|}
\hline \multicolumn{1}{|c|}{ Reasons for Participation } & Frequency $(\mathrm{n}=81)$ \\
\hline Unemployment & 39 \\
\hline Under employment & 3 \\
\hline Career diversification & 5 \\
\hline Skill acquisition & 34 \\
\hline
\end{tabular}

Source: field survey, 2018

The result in Table 2 could be likened to the fact that, in the Nigeria economy, graduates out of school are not totally opportune in finding white collar jobs due to a high unemployment rate (Taiwo, 2017; Anah, Nwosu, \& Ezeji, 2017). The only likely means of gaining means of livelihood is through self- employment which could be gotten from participating in a programme like IYA.

Views of respondents on incomes and the number of employed young people generated in cattle fattening

The result of the views of respondents on income and employment generated in cattle fattening is presented in Table 3. The result showed that all respondents in both categories (participants and nonparticipants in IYA) used one form of support or the other as the main source of start-up capital for their cattle fattening enterprise. All of the participants agreed that they received financial support after their training for the establishment of their business. For non-participants in the IYA programme, most of them started their cattle fattening business with the family and friends' support, as they were not given the right to the grant received by the participants of the IYA programme. Livestock farm size of respondents revealed that, the majority of IYA participants (39) have livestock holding of 5-10 cattle. With respect to non-participants, the majority of the respondents (48) have livestock holding of 1-4 cattle. This could be a result of the volume of funds gotten as a support for the start-up of their enterprise. In terms of farm size, the majority of respondents in both categories: 38 participants and 45 non-participants used below 1ha (that is between $0.5-0.9$ ha) for their enterprise. Regarding income generation, IYA programme participants on average earn higher income (NGN 71,093) than non-participants (NGN 31,000) of IYA programme. This implies that IYA programme actually has a positive influence on income generation of the participants in the study area. 


\section{Distribution of respondents' views on incomes and the number of employed} people generated through IYA

\begin{tabular}{|c|c|c|}
\hline & Participated(n-81) & Non -participated $(\mathrm{n}=60)$ \\
\hline Main source of capital & Frequency & Frequency \\
\hline Grant & 81 & 0 \\
\hline Family and friend support & 0 & 60 \\
\hline \multicolumn{3}{|c|}{ Receive financial support after training for the establishment of business } \\
\hline Yes & 81 & $\mathrm{Na}$ \\
\hline No & 0 & $\mathrm{Na}$ \\
\hline \multicolumn{3}{|l|}{ Farm location } \\
\hline Biu, Borno & 81 & 60 \\
\hline \multicolumn{3}{|l|}{ Livestock farm size } \\
\hline $1-4$ & 29 & 48 \\
\hline $5-10$ & 39 & 12 \\
\hline $11-15$ & 13 & 0 \\
\hline \multicolumn{3}{|c|}{ Employment generation } \\
\hline $1-3$ & 27 & 55 \\
\hline $4-6$ & 39 & 5 \\
\hline$\geq 7$ & 8 & \\
\hline \multicolumn{3}{|l|}{ Farm size (ha) } \\
\hline $0.5-0.9$ & 38 & 45 \\
\hline $1.0-1.4$ & 27 & 10 \\
\hline $1.5-1.9$ & 16 & 5 \\
\hline$\geq 2.0$ & 5 & \\
\hline \multicolumn{3}{|l|}{ Monthly income level (NGN) } \\
\hline $10,000-30,000$ & 10 & \\
\hline $31,000-50,000$ & 21 & 29 \\
\hline $51,000-70,000$ & 28 & 31 \\
\hline$\geq 71,000$ & 22 & \\
\hline Mean & 71,093 & 31,000 \\
\hline
\end{tabular}

Source: Field Survey, 2018

With respect to the employment generation, 39 IYA programme participants generated between 4-6 employment opportunities, while 55 non-participants generated between 1-3 employment cases. This implied that the programme had not only empowered the participants, but it had also made the participants become employers.

\section{Conclusion}

Regarding all above mentioned, the study concludes that one of the ways of reducing unemployment rate in Nigeria as a whole is through organizing capacity building and development training for school graduates to be gainfully engaged in economic activities via self-employment and in the 
long run become employers. The study recommended that as a way of reducing graduate unemployment, there is a need to support youths with funds, assist them to access trainings on capacity development and skill acquisition to make them self-employed and create more job opportunities.

\section{References}

1. Adeiga, A.F.C. (1997). Organisation of children in Agriculture in rural secondary schools in AgoIwoye, Ogun State. Lecture delivered at Ijebu Ode,Ogun State. In: Arowolo, O.O., Lawal, A.M and Ogundijo, J.I. (2013). Grass-root youth involvement in cattle activities Oyo State, South western Nigeria. Journal of Agricultural Extension and Rural Development, 5(5):100106.

2. Agu, M.N. (2013). Need to empower Nigeria children and youths through information technology. International Journal of Soft Computing and Engineering, 2(6): 61-64.

3. Amadou, H., Dossa, L.H., Lompo, D.J.P., Abdulkadir, A., \& Schlecht, E. (2012). A comparison between urban livestock production strategies in Burkina Fas, Mali and Nigeria in West Africa. Tropical Animal Health and Production, 44(7):1631-1642.

4. Anah, C.I., Nwosu, A, \& Ezeji N. (2017). Graduate Unemployment in Nigeria: Implication for National Development. African Journal Online, 14 (1).

5. Erebor, O. (2003). Comprehensive Agricultural Science for senior secondary schools. Johnson Publishers Limited, Lagos. In: Arowolo, O.O., Lawal, A.M and Ogundijo, J.I. (2013). Grass- root youth involvemen in cattle activities Oyo State, South western Nigeria. Journal of Agricultural Extension and Rural Development, 5(5):100-106.

6. Mohammed, D., Mohammed, A., \& Dahiru, A. B. (2015). Determinants of Profitability of Cattle Fattening Scheme in Song Local Government Area, Adamawa State, Nigeria. Journal of Agricultural Economics, Environment and Social Sciences 1(1):155-162.

7. Okoye, B., Okorji, C., \& Asumugha, N. (2007). Economic efficiency of small-holder Cocoyam farmers in Anambra State Nigeria. Agricultural Journal, 2: 535-542.

8. Sarma, P.K., \& Ahmed, J.U. (2011). An economic study of small scale cattle fattening enterprise of Rajbari district. Journal of Bangladesh Agricultural University. 9(1): 141-146.

9. Sarma, P.K., Raha, S.K. \& Jørgensen, H. (2014). An economic analysis of beef cattle fattening in selected areas of Pabna and Sirajgonj Districts. Journal of Bangladesh Agricultural University, 12(1):127 - 134

10. Taiwo, S. (2017). Unemployed Nigerians: More Nigerian Graduates Become Jobless, Unemployment Rate Hits 21\%. Retrieved on May 8, 2018, from www.pulse.ng/bi/ politics/unemployed-nigerians-more-nigeriangraduates-become-jobless-unemploment-ratehits-21-id6790778.html.

11. Umar, A.S.S., Alamu, J.F., \& Adeniji, O.B. (2008). Economic Analysis of Small Scale Cow Fattening Enterprise in Bama Local Government Area of Borno State, Nigeria. Production Agriculture and Technology (PAT), 4(1):1-10. 